http://dx.doi.org/10.12775/szhf.2016.033

\author{
Justyna Czekajewska
}

Uniwersytet Medyczny im. Karola Marcinkowskiego w Poznaniu, Poznań, Polska

\title{
Racjonowanie zasobów zdrowotnych ze względu na wiek pacjenta. Głos w obronie jakości życia osób starszych*
}

\section{Wstęp}

Profesor Włodzimierz Galewicz we wstępie do debaty pt. Kryterium wie$k u$ wacjonowaniu zasobów zdrowotnych zadaje pytanie, które odnosi się do stosowania alokacji usług zdrowotnych ze względu na wiek pacjenta. Autor wypowiedzi rozważa:

* Artykuł został napisany na prośbę Interdyscyplinarnego Centrum Etyki Uniwersytetu Jagiellońskiego oraz Polskiego Towarzystwa Bioetycznego jako głos w debacie pt. Kryterium wieku $w$ racjonowaniu zasobów zdrowotnych. Celem dyskusji była prezentacja różnych poglądów z zakresu etyki i medycyny na temat podziału dóbr zdrowotnych ze względu na wiek pacjenta. Organizatorom internetowej debaty serdecznie dziękuję za zaproszenie. 
Czy istnieje powód, aby osobom w podeszłym wieku odmawiać bądź to w ogóle dostępu, bądź przynajmniej pierwszeństwa $\mathrm{w}$ dostępie do świadczeń zdrowotnych? ${ }^{1}$

W celu udzielenia odpowiedzi na zadane pytanie warto zwrócić uwagę na szczegóły. Założenie, że pacjent ze względu na starszy wiek może nie mieć dostępu do usług medycznych, budzi zastrzeżenia. Problematyczne staje się zarówno ustalenie wieku w przyznaniu pierwszeństwa dostępu do gwarantowanych usług medycznych, jak i wyjaśnienie, że omawiane kryterium może być powodem dyskryminacji pacjentów przez pracowników służby zdrowia. Obawy budzi więc zastosowanie niewłaściwych mechanizmów rynkowych, a wraz z tym wprowadzenie do systemu opieki medycznej zasad, które będą selekcjonowały pacjentów ze względów naturalnych.

Każdy człowiek ma świadomość, że wraz z upływem lat jego zdrowie fizyczne i psychiczne ulegnie pogorszeniu. Starość jest nieodłącznym etapem życia człowieka, dlatego w trakcie prowadzonych rozważań na temat podziału dóbr zdrowotnych, należy szczególnie zwrócić uwagę na potrzeby ludzi starszych, ponieważ ich oczekiwania będą w przyszłości dotyczyć każdego $\mathrm{z}$ nas.

Zainteresowanie tematem zdrowia przez tę grupę społeczną wynika nie tylko z konieczności, ale również z obaw. Osoby te wykazują szczególną wrażliwość na wszelkie dyskusje dotyczące opieki medycznej. Nierzadko pojawiają się lęki, których źródłem jest wyobrażenie starości bez towarzystwa rodziny, odrzucenie, bieda, demencja oraz inne schorzenia. Ludzie starsi i w podeszłym wieku obawiają się utraty kontaktu z osobami bliskimi i braku wsparcia, zwłaszcza w trudnych sytuacjach, kiedy choroba uniemożliwia samodzielne funkcjonowanie w społeczeństwie i odbiera godność. Niemniej jednak zależność od drugiego człowieka, rozumiana jako bezużyteczność, dodatkowy kłopot czy niepotrzebny balast, prowadzi do sytuacji, w której chory prosi rodzinę lub personel medyczny o skrócenie cierpienia i przyspieszenie śmierci, dlatego ważne jest zrozumienie oczekiwań osób starszych przez pracowników służby zdrowia oraz bliskich z kręgu rodziny, przyjaciół i sąsiadów nie tylko po to, żeby uniknąć nieporozumień, ale przede wszystkim, żeby nie prowokować sytuacji, w jakich osoba cierpiąca staje się ofiarą przemocy.

${ }^{1}$ W. Galewicz, Kryterium wieku $w$ racjonowaniu zasobów zdrowotnych, „Forum PTB i INCET"; http://www.incet.uj.edu.pl/dzialy.php?l=pl\&p=30\&i=388\&m=19\&n=1\&z=0\&k=43 [dostęp: 02.04.2016]. 
W artykule zamierzam zestawić poglądy etyków, psychologów oraz lekarzy na temat podziału dóbr zdrowotnych ze względu na wiek pacjenta. W tym celu najpierw wymienię i opiszę metody stosowane w medycynie i służące alokacji limitowanych usług zdrowotnych, a następnie wyjaśnię, dlaczego w trakcie rozłożenia świadczeń zdrowotnych warto wziąć pod uwagę jakość życia osób starszych, a nie sam wiek metrykalny. W trakcie prezentacji argumentów przedstawię wyniki badań prof. dr hab. Katarzyny Wieczorkowskiej-Tobis z Uniwersytetu Medycznego w Poznaniu, która wraz z zespołem badawczym opracowała czynniki determinujące poczucie dobrostanu osób starszych.

\section{Zdrowie - wartość najcenniejsza dla człowieka}

Zarówno w Polsce, jak i w innych krajach Europy postępuje proces starzenia się ludności. Według danych Eurostatu wzrost odsetka osób powyżej 65 lat w 2030 roku wyniesie $23,8 \%{ }^{2}$. Wniosek uzasadniono przeprowadzonymi badaniami, z których wynika, że liczba urodzeń nieprzerwanie maleje od $1984 \mathrm{roku}^{3}$. Zdaniem badaczy wzrost osób w wieku poprodukcyjnym postępuje $\mathrm{z}$ dwóch powodów: wysokiego niżu demograficznego oraz wydłużenia przeciętnego okresu trwania życia ludzkiego ${ }^{4}$.

Wymienione argumenty potwierdzają informację, że popyt na usługi zdrowotne rośnie, a nawet często przewyższa innego rodzaju potrzeby, np. żywnościowe, mieszkaniowe czy edukacyjne. Współcześnie zdrowiu przypisuje się najwyższą wartość nie tylko dlatego, że przynależy ono do dóbr, ponieważ istnieją ich różne rodzaje, a ich wartość jest relatywna w zależności od subiektywnych upodobań ludzi i określonych grup społecznych. Przede

${ }^{2}$ S. Kropińska, E. Zasadzka, K. Wieczorowska-Tobis, Dyskryminacja osób $w$ wieku podeszłym w placówkach służby zdrowia, [w:] Człowiek $w$ wieku podeszłym we współczesnym społeczeństwie, red. D. Talarska, K. Wieczorowska-Tobis, Wydawnictwo UMP, Poznań 2009, s. 51. Por. Eurostat 2008:Proportion of population aged 65 and over, http://epp.eurostat.ec.europa.eu/tgm/table.do? tab=table\&init $=1$ \&plugin $=1$ \&language $=$ en $\&$ pcode $=$ tps00028 $\quad$ dostęp: 02.04.2016].

${ }^{3}$ Demografia Polski - Raport GUS; http://www.clf.net.pl/15-demografia-polski [dostęp: 02.04.2016].

${ }^{4}$ T. Kostka, M. Koziarska-Rościszewska, Choroby wieku podeszłego, Wydawnictwo Lekarskie PZWL, Warszawa 2009, s. 12. 
wszystkim zyskuje ono na wartości, ponieważ należy do skończonych zasobów ${ }^{5}$. Zdaniem Kazimierza Szewczyka społeczne zainteresowanie usługami zdrowotnymi jest nieograniczone, dlatego:

[...] w przypadku niewystarczających zasobów mamy do czynienia zarówno z konkurencją między jednostkami i grupami, jak i społeczną kooperacją mającą na celu lepsze wykorzystanie limitowanych dóbr ${ }^{6}$.

Współzawodnictwo w dostępie do świadczeń zdrowotnych wprowadza nierówności i sprawia, że niektóre grupy społeczne (seniorzy, niepełnosprawni) czują się pokrzywdzone. Ich wykluczenie z grona osób, którym przypisuje się pierwszeństwo $\mathrm{w}$ dostępie do usług medycznych, jest często argumentowane niedoborem środków finansowych, ale w rzeczywistości ma ono związek $\mathrm{z}$ „naturalnie limitowanymi dobrami w medycynie”, np. przeznaczeniem narządów do transplantacji czy transfuzją krwi. Ponadto bardzo ważną rolę odgrywa jakość życia pacjenta, czyli kondycja jego organizmu. Jak słusznie zauważył prof. W. Galewicz, jedną z najbardziej znanych metod stosowanych w medycynie, w celu oceny wpływu poszczególnych chorób (wypadków) na zdrowie i życie pacjenta, jest wskaźnik określany jako liczba lat skorygowana o jakość - QALY (Quality Adjusted Life Year) ${ }^{8}$. Metoda ta służy do obliczania lat życia utraconych przedwcześnie ze względu na ciężki stan zdrowia lub niepełnosprawność. Innymi słowy, wycenia jakość życia pacjentów na podstawie przeżytych lat.

Stosowanie QALY łącznie z innymi wskaźnikami (DALY, HALE, HRQL) ${ }^{9}$ jest powszechnie zatwierdzone przez WHO (World Health Organization). Definiowanie jakości życia jako pełnego dobrostanu fizycznego, społecznego

${ }^{5}$ K. Szewczyk, Bioetyka. Pacjent $w$ systemie opieki zdrowotnej, Wydawnictwo Naukowe PWN, Warszawa 2009, s. 14.

${ }^{6}$ Tamże.

7 Tamże.

${ }^{8}$ T. Kostka, M. Koziarska-Rościszewska, dz. cyt., s. 174.

Por. W. Galewicz, Kryterium wieku w racjonowaniu zasobów zdrowotnych, „Forum PTB i INCET"; http://www.incet.uj.edu.pl/dzialy.php?l=pl\&p=30\&i $=388 \& \mathrm{~m}=19 \& \mathrm{n}=1 \& \mathrm{z}=0 \& \mathrm{k}=43$ [dostęp: 02.04.2016].

${ }^{9}$ DALY - disability adjusted life years (liczba lat skorygowanych o niepełnosprawność); HALE - healthy life expectancy (oczekiwana liczba lat przeżytych w zdrowiu); HRQL - health related quality of life (jakość życia uwarunkowana zdrowiem).

T. Kostka, M. Koziarska-Rościszewska, dz. cyt., s. 174; por. „NICE - National Institute for Health and Care Excellence", https://www.nice.org.uk/news [dostęp: 02.04.2016]. 
i umysłowego człowieka nasuwa jednak skojarzenia, że stosowanie ogólnej zasady ekonomicznej opłacalności może być niewystarczające. Zdaniem niektórych naukowców oraz specjalistów w zakresie oceny technologii medycznych, takich jak: Amanda Brower i Elan Rubinstein, skuteczność leczenia metodą QALY jest dyskusyjna. Według opinii uczonych do systemu zostają wprowadzone nowe leki, których efektywność ocenia się długością życia pacjenta. W trosce o bezpieczeństwo chorych agencje rządowe powinny więcej uwagi poświęcić skutkom ubocznym nowo refundowanych leków. Niektóre $\mathrm{z}$ nich jedynie łagodzą objawy. Pozornie poprawiają kondycję zdrowia pacjenta, podczas gdy w rzeczywistości choroba postępuje ${ }^{10}$.

Jakości zdrowia pacjenta nie można mierzyć wyłącznie długością życia. Sprowadzenie wartości zdrowia do przeżytych lat jest uproszczoną kalkulacją. Metoda ta nie jest wystarczająca i prezentuje rozwiązanie problemu (ocenę korzyści) z pozycji pracowników służby zdrowia. Nie zawsze bowiem to, co z perspektywy pracownika medycznego wydaje się najlepsze dla pacjenta, jest tak przez niego odbierane. Tak jak odróżnia się wiek metrykalny od biologicznego, tak samo należy przyjąć, że wartość zdrowia jest zależna od

dobrej kondycji, a nie od wieku kalendarzowego osoby starszej. Jakość życia ludzkiego zostaje wyrażona w subiektywnej opinii pacjentów ${ }^{11}$. Zdaniem Tomasza Kostki:

Kluczowym wyzwaniem jest ocena, które choroby, aspekty fizyczne, psychiczne i społeczne, są czynnikami determinującymi jakość życia ${ }^{12}$.

Gorsza jakość zdrowia osób starszych jest zależna od wielu schorzeń, m.in. nadciśnienia tętniczego, cukrzycy, chorób niedokrwiennych serca, przebytego

\footnotetext{
${ }^{10}$ A. Brower, Is It Time To Take a Harder Look at the QALY?, „National Center for Biotechnology Information", http://www.ncbi.nlm.nih.gov/pmc/articles/PMC2706179/ [dostęp: 02.04.2016].

${ }^{11}$ Helena Sęk w książce pt. Wprowadzenie do psychologii klinicznej prezentuje dwa typy odczuć. Pierwszym z nich jest obiektywne poczucie dobrostanu, a drugim subiektywne poczucie dobrej jakości życia. Obiektywne poczucie rozumiane jest jako zespół warunków fizycznych, socjalnych, społeczno-kulturowych, które budują wizerunek jednostki w społeczeństwie. Subiektywne poczucie wynika z oceny i wartości całego życia, czyli jest rezultatem doświadczeń życiowych decydujących o poczuciu własnej wartości i spełnienia. H. Sęk, Wprowadzenie do psychologii klinicznej, Wydawnictwo Naukowe Scholar, Warszawa 2001.

${ }^{12}$ T. Kostka, M. Koziarska-Rościszewska, dz. cyt., s. 175.
} 
zawału mięśnia sercowego, udaru mózgu czy złamania szyjki kości udowej ${ }^{13}$, ale wymienione przyczyny utraty zdrowia są konsekwencją nie tylko złych przyzwyczajeń, lecz także trudnej sytuacji życiowej i nieszczęśliwych wypadków.

Wspominam o tym, ponieważ we współczesnej literaturze medycznej najwięcej uwagi poświęca się rozpoznaniu chorób wieku podeszłego. Warto zauważyć, że wspominane schorzenia nie dotyczą wyłącznie osób starszych, lecz coraz częściej młodszego pokolenia, dlatego badania medyczne powinny być uzupełnione o inne czynniki, które determinują subiektywne poczucie dobrostanu w fazie starzenia się.

\section{Czynniki uniemożliwiające poczucie dobrostanu u kobiet i mężczyzn w okresie starości}

Pogorszenie jakości zdrowia osób starszych często zależy od płci, miejsca zamieszkania, stanu cywilnego i majętności. Anna Klatkiewicz w artykule Poczucie dobrostanu i satysfakcji życiowej u kobiet $w$ fazie starzenia się dokonuje przeglądu współczesnych badań nad potrzebami i problemami kobiet starszych, w celu rozpoznania czynników, które mają wpływ na ich subiektywne poczucie jakości życia. Autorka łączy poczucie dobrostanu ze sferą psychiczną człowieka i zwraca uwagę na: zaspokojenie potrzeb osobistych, poczucie bezpieczeństwa, kontakty z innymi ludźmi, przyjaźń, bliskość oraz radość i zabawę ${ }^{14}$. Bez wątpienia zakres potrzeb mógłby zostać rozszerzony, gdyby uwzględnić spełnienie intelektualne, ale wymienione czynniki są na tyle wystarczające, że pozwalają trafnie ocenić, z jakimi problemami zmagają się starsze kobiety.

Panie bardzo często odczuwają lęki, depresję, pesymizm, troskę, samotność oraz wewnętrzny niepokój, dlatego też są społecznie postrzegane jako osoby apatyczne, nieuprzejme i pogrążone w smutku. W latach 90. minionego wieku Pernilla Hilleras wykazała, że stan przygnębienia u kobiet jest spowodowany zmniejszeniem szans doświadczania pozytywnych doznań, na skutek

\footnotetext{
13 Tamże.

${ }^{14} \mathrm{~K}$. Baumann, Jakość życia w okresie późnej dorosłości - dyskurs teoretyczny, „Gerontologia Polska" 2006, t. 14, nr 4.
} 
braku zaangażowania $\mathrm{w}$ społeczne aktywności ${ }^{15}$. Współcześnie podobnie argumentuje Martin Pinquart. Zdaniem badacza zmniejszenie odczuwania pozytywnych emocji postępuje wraz z wiekiem, powodując zachwianie równowagi emocjonalnej ${ }^{16}$. Im kobiety są starsze, tym częściej odbierają potrzeby dzieci oraz wnuków jako ważniejsze od swoich. Indywidualne pragnienia ustępują miejsca rodzinnym zobowiązaniom, dlatego przestają artykułować swoje oczekiwania. Stłamszenie emocji powoduje obniżenie poczucia satysfakcji i zadowolenia, wobec czego w późnym wieku u kobiet następuje wzrost afektów negatywnych, które sprzyjają obniżeniu energii psychicznej i fizycznej. Rezygnacja $z$ wszelkich form aktywności sprawia, że panie spędzają czas we własnych domach, brakuje im towarzystwa, zaczynają odczuwać samotność, a nawet zdarza się, że mają myśli samobójcze ${ }^{17}$. Pomocą w przezwyciężeniu trudności może być wybór właściwego miejsca zamieszkania. Słowo „właściwe” rozumiem jako odpowiadające indywidualnym potrzebom ${ }^{18}$. Z badań statystycznych wynika, że kobiety, które zdecydowały się mieszkać na osiedlach w większości zamieszkałych przez seniorów, szybciej nawiązywały relacje i potrafiły je utrzymać niż osoby, które albo spędzały czas wyłącznie z członkami rodziny, albo nie miały możliwości nawiązania nowych znajomości ${ }^{19}$.

${ }^{15}$ P. K. Hilleras, A. F. Jorm, A. Herlitz, B. Winblad, Negative and positive affect among the very old, „Research on Aging” 1998, no. 20, s. 593-610.

${ }^{16}$ M. Pinquart, Age differences in perceived positive affect, negative affect and affect balance in middle and old age, „Journal of Happiness Studies” 2001, no. 2, s. 375-405.

${ }^{17}$ G. C. Wenger, Morale in old age: a review of the evidence, „International Journal of Geriatric Psychiatry" 1992, no. 7, s. 699-708.

${ }^{18}$ Dziś rodzinę coraz częściej tworzą układy sieciowe seniorów. Osoby starsze, które mieszkają z dala od swoich dzieci i wnuków, nie mogą liczyć na codzienną ich pomoc muszą same zaopiekować się własnym gospodarstwem domowym. Pomimo dużej swobody i wolnego czasu, zmagają się z samotnością. Brakuje im wspólnoty przyjaciół i rodziny. Niektórzy postanowili więc wypełnić brak kontaktu z krewnymi nowymi przyjaciółmi, których potrzeby są zbliżone. Seniorzy wzajemnie się o siebie troszczą, opiekują się sobą i wspierają w trudnych sytuacjach, takich jak: utrata zdrowia, śmierć współmałżonka, trudności finansowe i wykluczenie z grona rodziny. Wzajemnie oferują sobie pomoc, dlatego tak wielu z nich decyduje się wspólnie mieszkać i dzielić koszty. Osoby bardziej zamożne postanawiają też migrować wewnątrz kraju, np. do osiedli dla seniorów. C. Phillipson, A. Graham, Aging and the Life Course, [w:] The Blackwell Companion to the Sociology of Families, eds. J. Scott, J. Treas, M. Richards, Blackwell Publishing, Oxford 2007, s. 126-141.

${ }^{19}$ Tamże, s. 699-708. 
[Ponadto] kobiety wykazują znacznie większą umiejętność niż mężczyźni tworzenia sieci związków przyjacielskich z rozległym wsparciem, które przekazują innym i same otrzymują ${ }^{20}$.

Panowie w mniejszym stopniu od pań koncentrują uwagę na więzi społecznej, unikają tworzenia nowych relacji międzyosobowych oraz zwierzania się ze spraw osobistych znajomym. Warto podkreślić, że mężczyźni w starszym wieku są w bardzo trudnej sytuacji, niejednokrotnie trudniejszej od ich rówieśniczek, ponieważ muszą zredefiniować pojęcie męskości.

Współcześnie uważa się, że „męskość” jest kategorią społecznie konstruowaną przez różne kultury i historię ${ }^{21}$. Wielu mężczyzn jednak nie akceptuje zmian, jakie zachodzą wraz z wiekiem i są wymuszane przez społeczeństwo. Innymi słowy, nie przyjmują wszystkich wzorów męskości, dlatego pielęgnują wysoką ocenę własnej osoby w oczach innych ludzi, chcą bowiem uchodzić za silnych, pewnych siebie i doświadczonych. W opinii Urszuli Kluczyńskiej i Edwarda Thomsona najtrudniejszy etap w życiu mężczyzny ma związek z przejściem na emeryturę.

Panowie odbierają to, jako spadek z piedestału lub ustąpienie miejsca „na scenie" młodszym ${ }^{22}$.

Zdaniem większości mężczyzn emerytura nie ma związku z zagospodarowaniem czasu wolnego, wspólnymi, rodzinnymi wycieczkami i pomocą w wychowaniu wnuków. Dla nich jest to przede wszystkim strata pozycji zawodowej, niezależności, statusu i zdrowia. Problemy wieku podeszłego wynikają więc ze społecznie skonstruowanego wizerunku mężczyzny oraz wzorów, które zostały utrwalone w rodzinie. Panowie często odczuwają niezadowolenie, a czasem i gniew, kiedy mają wykonywać prace przeznaczone dla kobiet. Sprzątanie mieszkania, gotowanie, opieka nad wnukami, a także organizacja uroczystości rodzinnych to zadania, które w oczach mężczyzn

${ }^{20}$ A. Klatkiewicz, Poczucie dobrostanu i satysfakcji życiowej u kobiet $w$ fazie starzenia się, [w:] Człowiek w wieku podeszłym..., s. 33.

${ }^{21}$ Examining Masculinities, [w:] R. W. Connell, The Man and the Boys, University of California Press, Berkley-Los Angeles 2000, s. 1-14.

22 U. Kluczyńska, Stary mężczyzna we współczesnym społeczeństwie. Konteksty społeczne i kulturowe, [w:] Człowiek w wieku podeszłym..., s. 43. Por. H. E. Thomson Jr., Older Man as Invisible Man in Contemporary Society, [w:] Men's Lives, eds. M. S. Kimmel, M. A Messner, Allyn and Bacon, Boston-London-Toronto-Sidney-Tokyo-Singapore 1998, s. 68-84. 
uchodzą za kobiece, dlatego nie chcą ich wykonywać. Uważają, że przejęcie domowych obowiązków kreuje nowy wizerunek starego mężczyzny, który musi wyrzec się swojej męskości ze względu na wiek. Ponadto mężczyźni niechętnie godzą się na uczestnictwo w spotkaniach w klubach seniora, a swoją odmowę argumentują tym, że większość zajęć jest organizowana z myślą o kobietach ${ }^{23}$.

Czy prezentowane argumenty są słuszne, czy jest to wyłącznie wymówka? Okazuje się, że panowie mówią prawdę. Kobiety w grupie osób starszych przeważają liczbowo, a skoro jeszcze w latach młodości opiekowały się dziećmi, chodziły na wywiadówki, rozmawiały z nauczycielami oraz inicjowały znajomości koleżeńskie i przyjacielskie, to sfera budowania kontaktów społecznych nie sprawiała im trudności. Dzisiaj starsze panie, które nie odczuwają braków finansowych, chętnie angażują się w sprawy społeczne i religijne. Odwiedzanie klubów seniora bądź uniwersytetów trzeciego wieku sprawia im również dużo przyjemności. Panowie rzadko uczestniczą w dodatkowych zajęciach, ponieważ ich zdaniem nie ma odpowiedniego programu, którym mogliby być zainteresowani. Zajęcia przeważnie organizowane są $\mathrm{z}$ myślą o większości, a w tym przypadku są to reprezentantki płci pięknej, dlatego mężczyźni rezygnują z możliwości spędzania czasu wolnego w towarzystwie nowo poznanych osób. Nie tylko wycofują się z wszelkich form rozrywek, ale po prostu „znikają” ze sfery społecznej i lokalnej.

\section{Dyskryminacja osób starszych ze względu na wiek}

Izolacja od społeczeństwa jeszcze bardziej pogłębia się, gdy umiera żona, wówczas panowie unikają zwierzeń i cierpią w samotności. Przeżywanie straty, jeśli nie zostanie oswojone, to przechodzi w etap bezradności, osamotnienia i lęku, czego konsekwencją mogą być m.in.: depresja, niska ocena własnej wartości, wzmożone picie alkoholu oraz brak higieny.

Mężczyźni najczęściej czują się wtedy marginalizowani i wykluczeni. Według badań A. Petersa i A. C. Liefbroera strata współmałżonka jest bardziej niekorzystna dla mężczyzn niż kobiet ${ }^{24}$. Nie tylko dlatego, że z konieczności

\footnotetext{
${ }^{23}$ Tamże, s. 44.

${ }^{24}$ F. M., Alpass, S. Nevile, Loneliness, health and depression in older males, „Aging \& Mental Health" 2003, vol. 7, Iss. 3, s. 2012-2016.
} 
muszą przejąć obowiązki domowe, ale przede wszystkim muszą przedefiniować własną tożsamość i nawiązać emocjonalną bliskość z dziećmi oraz ich rodzinami ${ }^{25}$. Zadanie to wymaga poświęcenia i jest szczególnie trudne dla tych mężczyzn, którzy dotychczas nie próbowali szczerze rozmawiać ze swoimi dziećmi, a one nie miały ochoty i odwagi zwierzać się ze spraw osobistych swoim ojcom.

W sytuacji, gdy rodzice tracą dobre relacje z dziećmi, to poczucie opuszczenia pogłębia się, a skrywany żal przechodzi w smutek. Takie uczucia przejawiają osoby pozostawione w domach spokojnej starości i szpitalach. Czują się niepotrzebni, porzuceni, a negatywne uczucia potęguje zależność od innych ludzi, często obcych, którzy nigdy nie zastąpią bliskich z kręgu rodziny.

Dla osób starszych przebywanie poza domem, np. w różnych ośrodkach opieki, kojarzy się z postępującą niedołężnością, dlatego jest czymś nieakceptowanym. Negatywny obraz starości zostaje wzmocniony, jeśli pacjent jest świadkiem złego traktowania albo sam pada ofiarą krzywdzących opinii ze strony personelu medycznego.

Dyskryminacji ze względu na wiek ${ }^{26}$ można doświadczyć na różne sposoby - istnieją formy bezpośrednie i pośrednie (jawne i ukryte). Agresja może zostać wyrażona przez lekceważenie, pogardę, ośmieszenie, zaniedbanie, a nawet stosowanie przemocy fizycznej, finansowej oraz seksualnej i psychicznej ${ }^{27}$. Ageizm uwidacznia się także w sytuacji, w której pacjent jest traktowany mniej kompetentnie, odbiera się mu możliwość decyzji, nie słucha jego zdania i traktuje nadopiekuńczo.

${ }^{25}$ Temat ten w interesujący sposób został przedstawiony w filmie Kirka Jonesa Everybody's fine z 2009 r. Frank po śmierci swojej żony uświadamia sobie, że ich dzieci miały dobry kontakt wyłącznie z matką. Ze względu na pracę i liczne obowiązki Frank nie mógł angażować się w wychowanie dzieci, zaniedbał opiekę, dlatego one oddaliły się od niego. Po latach fizycznej i emocjonalnej rozłąki, ojciec chce odnowić dobre kontakty z dziećmi, tak samo jak wcześniej czyniła to jego żona.

${ }^{26}$ Istnieją różne formy dyskryminacji, np. rasizm, ksenofobia, seksizm, homofonia, handicapizm, agezim, ale tylko jedna z nich dotyczy osób starszych. Termin „ageizm” został wprowadzony do literatury naukowej w 1969 r. przez Roberta Neila Butlera (amerykańskiego fizyka, gerontologa i psychiatrę). Uznał on, że seksizm, rasizm oraz ageizm należą do najpoważniejszych problemów współczesnego świata i stanowią zagrożenie dla zrównoważonego rozwoju społecznego. Według opinii tego badacza ageizm to proces systematycznego konstruowania stereotypów, które są podstawą do dyskryminacji osób wyłącznie ze względu na podeszły wiek. Por. http://ageismhurts.org/what-is-ageism [dostęp: 02.04.2016].

${ }^{27}$ E. Sygit, R. Ossowski, Przemoc wobec osób starszych ze względu na wiek, płeć i wykształcenie, „Gerontologia Polska” 2008, nr 16, s. 163-168. 


\section{Ustalenie priorytetów w systemie opieki zdrowotnej}

Choroby, bariery językowe, problemy z przyswajaniem nowych informacji, ubóstwo i mniejsza zaradność tylko wspierają stereotypy, tworząc wyobrażenie starości, która jest najtrudniejszym etapem w życiu każdego człowieka. Starość jest społecznie niechętnie odbierana, dlatego wszelkie działania zmierzają w stronę troski o jakość życia, która staje się dziś światowym lobby. $\mathrm{W}$ promocję zdrowia zaangażowane są kluby sportowe, ekologiczne restauracje, sklepy ze zdrową żywnością, a także firmy ubezpieczeniowe. Szczególnie instytucje finansowe z myślą o problemach osób starszych nakłaniają do wykupienia dodatkowych pakietów, które gwarantowałyby bezpieczeństwo opieki w chwili utraty zdrowia. Firmy prywatne współtworzą model organizacyjny opieki, w którym obok świadczeń gwarantowanych istnieją usługi rekomendowane i procedury uzupełniające ${ }^{28}$.

Przyjęcie strategii tworzenia systemu opieki zdrowotnej opartej na różnego rodzaju świadczeniach dziś nie jest przedmiotem sporów, jak w latach 80. XX wieku ${ }^{29}$. Problemem nie jest budowanie modelu, który łączy różne rodzaje usług. Najtrudniejszym zadaniem jest ustalenie priorytetów w systemie opieki zdrowotnej, czyli jak kierować pracą poszczególnych grup ekspertów, żeby nie naruszyć etycznych zasad i demokratycznych standardów w trakcie rozwiązywania problemów rozdzielnictwa usług zdrowotnych.

Gremium ekspertów, to nie tylko lekarze i pielęgniarki, ale przedsiębiorstwa medyczne, związki zawodowe, dyrekcje szpitali, politycy, media oraz pracownicy administracji. Zadania wymienionych podmiotów są różne, ale powinny się wzajemnie uzupełniać. Administracja dba o efektywność oraz

\footnotetext{
${ }^{28}$ Zdaniem Kazimierza Szewczyka: „do zakresu świadczeń rekomendowanych należałyby procedury o potwierdzonej skuteczności, ale których relacja koszt-efekt „nie jest dostatecznie zadowalająca". Inaczej mówiąc, proponuje się tu umieścić usługi dobroczynne, ale zbyt drogie, na które w aktualnej sytuacji finansowej społeczeństwo nie może sobie pozwolić. Pacjent musiałby współfinansować ten typ świadczeń, przede wszystkim z dodatkowych prywatnych ubezpieczeń". K. Szewczyk, dz. cyt., s. 35.

${ }^{29}$ Pierwsza ważna propozycja filozoficzna na temat sposobu racjonowania opieki zdrowotnej została przedstawiona w 1985 r. Jej twórca, Norman Daniels (obecnie wykładowca akademicki, nauczyciel etyki i zdrowia publicznego Uniwersytetu Harvarda), opowiada się za modelem sprawiedliwej opieki zdrowotnej. Poglądy uczonego są bliskie teorii sprawiedliwości Johna Rawlsa, dlatego w książce Just Health Care autor sądzi, że państwo ma moralny obowiązek zapewnienia swoim obywatelom równości w dostępie do świadczeń zdrowotnych. N. Daniels, Just Health Care, Oxford University Press, New York 1985.
} 
ekonomiczną opłacalność, dyrekcja placówki służby zdrowia kontroluje prace personelu i zgodność świadczonych usług z przepisami, a lekarze w myśl przysięgi Hipokratesa troszczą się o każdego pacjenta.

Podział zadań poszczególnych jednostek jest sprawiedliwy i zgodny z ideą solidarności, ale czy jest on wystarczający, aby ustalić granicę między usługami gwarantowanymi a rekomendowanymi? Inaczej mówiąc, czy można zgodzić się na ekonomiczne rozdzielnictwo opieki zdrowotnej?

Dziś trudno sobie wyobrazić, że system opieki medycznej ma inne niż powszechnie obowiązujące standardy. Niepokój budzi jednak świadomość, że niektóre zasady prawne są sprzeczne z nakazami etyki, ponieważ sprzyjają odmowie świadczeń zdrowotnych, w celu poczynienia oszczędności finansowych dla innego pacjenta, który ma lepsze rokowania zdrowotne ${ }^{30}$.

Taka sytuacja może również dotyczyć pierwszeństwa w dostępie do refundowanych leków. Pacjenci, u których stwierdzono nawrót choroby nowotworowej, mają mniejsze szanse finansowania leczenia ze środków publicznych. Chorych poddaje się klasyfikacji, a kryterium wieku i stan zdrowia odgrywają bardzo ważną rolę w rozdzielnictwie świadczeń zdrowotnych. Pacjenci $\mathrm{w}$ zaawansowanym stopniu choroby nowotworowej nie mają szans powrotu do zdrowia, a ponieważ dostępne leki wchodzą w zakres dóbr limitowanych, dlatego odmawia się leczenia, wydając decyzję, że koszty nie mogą być pokryte przez Narodowy Fundusz Zdrowia. Refundacja leków u chorych na raka należy wprawdzie do usług gwarantowanych, ale nie każdy pacjent onkologii ma prawo pierwszeństwa $\mathrm{w}$ dostępie do wskazanych świadczen ${ }^{31}$.

\footnotetext{
${ }^{30}$ Według opinii dr. med. Jarosława Derejczyka, gerontologa, dyrektora Szpitala Geriatrycznego im. Jana Pawła II w Katowicach: „Obowiązujące regulacje prawne, stosowane dotychczas przez Narodowy Fundusz Zdrowia (NFZ), w widoczny sposób dyskryminują osoby starsze. Dotyczy to nierównego dostępu do zakresu świadczeń na oddziałach geriatrycznych, deficytowego katalogu usług medycznych przypisanych geriatrii, innego poziomu ich opłacania $\mathrm{w}$ różnych regionach kraju, utrudnień w dostępie do sprzętu rehabilitacyjnego, którego w Polsce nie mają prawa zlecać - geriatrzy, a mają felczerzy”. Por. J. Derejczyk, B. Bień, J. Kokoszka-Paszkot, J. Szczygieł, Gerontologia i geriatria w Polsce na tle Europy - czy należy inwestować w ich rozwój w naszym kraju?, „Gerontologia Polska” 2008, nr 3 (16), s. 152-153. https://journals.viamedica.pl/gerontologia_polska/article/view/18941 [dostęp: 30.03.2016].

${ }^{31}$ Ilona Godlewska w artykule Anna jest chora na raka jajnika, ale lek jej nie przysługuje, opisuje historię choroby Anny Bojarskiej. Bohaterka wyjaśnia szczegóły zmagań z systemem NFZ, który nie chce wspomóc finansowo jej leczenia. Powodem odmowy przyznania świadczeń jest wcześniejsze skorzystanie z leczenia systemowego. Zgodnie z zasadami przyznania pierwszeństwa w dostępie do usług zdrowotnych pacjenci, którzy są w II linii leczenia choroby nowotworowej, muszą w całości pokryć koszty leczenia. Finansowanie ze środków publicz-
} 
Analogiczna sytuacja dotyczy geriatrii. Ta dziedzina medycyny jest niedoszacowana finansowo przez Narodowy Fundusz Zdrowia. Pomimo społecznej świadomości, że pacjentów w starszym wieku przybywa, nie dostrzega się potrzeb inwestowania w nowe oddziały geriatryczne. Zdaniem Katarzyny Wieczorkowskiej-Tobis, kierownika Katedry Geriatrii i Gerontologii Uniwersytetu Medycznego w Poznaniu:

W całej Wielkopolsce są dwa [odziały] - w Gnieźnie i w Ostrowie. W Warszawie, podobnie jak w Poznaniu, w ogóle nie ma łóżek przeznaczonych specjalnie dla osób starszych ${ }^{32}$.

Podobna sytuacja występuje $\mathrm{w}$ innych województwach. Według opinii Pani Profesor do 2012 roku nie było oddziałów geriatrycznych w czterech województwach (łódzkim, świętokrzyskim, warmińsko-mazurskim i pomorskim).

Dziś sytuacja ulega stopniowej poprawie, ale podany przykład ilustruje, jak ważnymi tematami są geriatria i gerontologia. Brak miejsc opieki nad osobami starszymi to również niedobór lekarzy geriatrów. Młodzi adepci szkół medycznych najczęściej nie wybierają tej profesji, ponieważ obawiają się braku angażu. Specjalizację w zakresie geriatrii można uzyskać po medycynie rodzinnej, chorobach wewnętrznych, więc lekarz musi posiadać taką samą wiedzę jak specjalista innego działu medycy, a zaangażowanie w pracę, nie-

nych przyznaje się tylko pacjentom w I linii leczenia. Pacjenci, którzy mają utrudniony dostęp do refundowanych leków, często czują się dyskryminowani. Według ich opinii system opieki zdrowotnej jest skonstruowany z myślą o osobach mających największe szanse powrotu do zdrowia. W rzeczywistości procedury dotyczące oceny jakości nowych technologii medycznych nie są konstruowane po to, żeby wyłącznie nieliczni pacjenci otrzymali pomoc. Zanim nowy lek zostanie wprowadzony do rejestru, ocenia się jego skuteczność i bezpieczeństwo. Jeśli okaże się, że nie wykazuje on przewagi w porównaniu z obecnie istniejącym lekiem, to trafia do drugiej kategorii. Wyłącznie te leki, które otrzymały miano innowacji, otrzymują pierwszą kategorię i więcej kosztują. Według opinii krytyków dodatkowym zarzutem wobec metody QALY jest brak badań porównawczych (komparatywnych), dlatego istnieją poważne wątpliwości, czy korzystanie z tej metody prowadzi do sprawiedliwego podziału publicznych środków. I. Godlewska, Anna jest chora na raka jajnika, ale lek jej nie przysługuje, http://wyborcza.pl/1,75248,17479257,Anna_jest_chora_na_raka_jajnika_ale_lek_jej_nie_przysluguje.html [dostęp: 02.04.2016]. Por. A. Brower, dz. cyt.

${ }^{32}$ A. Rozwadowska, Prof. Tobis-Wieczorkowska: W Poznaniu jest tylko kilku geriatrów. Ale coś sie powoli zmienia, http://www.gloswielkopolski.pl/artykul/772273,prof-tobiswieczorkowska-w-poznaniu-jest-tylko-kilku-geriatrow-ale-cos-sie-powoli-zmienia, 1,id,t,sa.html [dostęp: 02.04.2016]. 
ustanne dokształcanie się, budzą obawy, że bez oddziałów geriatrycznych nie ma potrzeby zatrudnienia nowych pracowników. Ponadto program kształcenia na uczelniach medycznych w całej Polsce dotychczas nie obejmował zajęć z elementów geriatrii. Zdaniem Jarosława Derejczyka, Barbary Bień, Janiny Kokoszka-Paszkot oraz Joanny Szczygieł:

Geriatria nadal nie została obowiązkowym przedmiotem nauczania na polskich uczelniach medycznych. Mimo wysiłków wielu gremiów gerontologicznych, Rada Główna Szkolnictwa Wyższego nie włączyła dotąd geriatrii do obligatoryjnego programu kształcenia na kierunku lekarskim. Dlatego jedynie połowa uczelni medycznych ma możliwość wykładania fakultatywnie przedmiotu "geriatria” w programie edukacji przyszłych lekarzy ${ }^{33}$.

Uniwersytet Medyczny w Poznaniu jako jeden z nielicznych wprowadził zmiany od października 2013 roku $^{34}$, dlatego przedmiot ten jest obowiązkowy na różnych kierunkach, zarówno medycznych, jak i nauk o zdrowiu ${ }^{35}$.

Badania naukowe prowadzone przez Katarzynę Wieczorkowską-Tobis dowiodły, że pacjent objęty fachową, kompleksową opieką geriatryczną mniej korzysta z pomocy lekarza rodzinnego. Innymi słowy, „nie wraca do systemu"36, dlatego rola geriatry w polskiej służbie zdrowia jest nieprzeceniona.

\section{Podsumowanie}

Moim zdaniem nie powinno się stosować zasady rozdzielnictwa dóbr zdrowotnych kosztem osób starszych. Przedstawione przykłady potwierdzają, jak często potrzeby tej grupy społecznej są dziś pomijane. Powołanie się na kryterium wieku uważam za niewystarczające. Postrzeganie osób starszych

\footnotetext{
${ }^{33}$ J. Derejczyk, B. Bień, J. Kokoszka-Paszkot, J. Szczygieł, dz. cyt.

${ }^{34}$ Tamże, s. 2.

${ }^{35}$ Wydział Nauk o Zdrowiu Uniwersytetu Medycznego im. Karola Marcinkowskiego w Poznaniu w latach 1975-2015. Czterdzieści lat w stużbie uniwersyteckich nauk medycznych, red. M. Musielak, W. Samborski, Wydawnictwo UMP, Poznań 2015, s. 116-119.

${ }^{36}$ „Jakiś czas temu przeprowadziliśmy ciekawe badania na Śląsku, gdzie pacjenci mają karty czipowe zawierające historię choroby. Przez rok śledziliśmy losy 2 tys. pacjentów interny i 2 tys. pacjentów geriatrycznych. Po roku pacjenci geriatryczni okazali się tańsi o 2 tys. zł „na głowę". To najlepszy dowód na to, że pacjent $\mathrm{z}$ dobrze zdefiniowanym problemem, poddany fachowemu leczeniu, nieprędko wraca pod opiekę lekarza". Tamże, s. 2.
} 
jako niepotrzebnych, bezużytecznych, wymagających nieustannej opieki jest nie tylko krzywdzące, ale świadczy o społecznej ignorancji i moralnej pustce. Zgodnie z najważniejszymi zasadami etyki medycyny powołaniem lekarza jest pomoc chorym.

Pracownik służby zdrowia w czasie codziennej praktyki w szpitalu nie powinien rozważać, czy przeprowadzić dodatkowe badania pacjentowi w podeszłym wieku. Jeśli istnieją uzasadnione obawy, należy niezwłocznie to uczynić.

Osobiście jestem zdania, że większość problemów zdrowotnych wynika z czynników obiektywnych i subiektywnych. Duży wpływ mają nie tylko niekorzystne miejsce zamieszkania i kłopoty finansowe, ale coraz częściej brak akceptacji społecznej, zły kontakt $\mathrm{z}$ dziećmi, a nawet brak możliwości korzystania $\mathrm{z}$ różnych form rozrywek.

Ogólne potrzeby ludzi starszych właściwie nie różnią się od potrzeb osób młodszych. Osoby w wieku początkowej starości (60-69 lat) chcą nadal aktywnie spędzać czas, podróżować i cieszyć się życiem. Potrzeby zmieniają się w kolejnych latach życia, ale tylko wtedy, gdy wraz z wiekiem ulega pogorszeniu sprawność fizyczna, intelektualna i psychiczna. Różnice stanu zdrowia wśród tej grupy osób pogłębiają się dopiero w późniejszym okresie, dlatego do definiowania progu starości nie powinno się używać wyłącznie wieku kalendarzowego. Dla każdego człowieka starość rozpoczyna się w innym okresie życia. Troska o dobrą kondycję fizyczną opóźnia procesy starzenia się, ale nie przyczynia się do poczucia dobrostanu, jeśli różne instytucje, a nawet osoby z kręgu rodziny będą nadal dyskryminować osoby starsze.

Starość nie powinna kojarzyć się wyłącznie z niedołężnością, apatią i utratą autonomii, ten okres w życiu ma również swoją stronę pozytywną. Mądrość życiowa, refleksyjność, bogate doświadczenie, znajomość świata i ludzi to bez wątpienia zalety, którymi mogą poszczycić się przede wszystkim osoby starsze. 


\section{Bibliografia}

Alpass F. M., Nevile S., Loneliness, health and depression in older males, „Aging \& Mental Health" 2003, vol. 7, Iss. 3.

Baumann K., Jakość życia w okresie późnej dorosłości - dyskurs teoretyczny, „Gerontologia Polska" 2006, t. 14, nr 4.

Connell R. W, The Man and the Boys, University of California Press, Berkley-Los Angeles 2000.

Daniels N. , Just Health Care, Oxford University Press, New York 1985.

Hilleras P. K., Jorm A. F., Herlitz A., Winblad B., Negative and positive affect among the very old, „Research on Aging” 1998, no. 20.

Klatkiewicz A., Poczucie dobrostanu i satysfakcji życiowej u kobiet $w$ fazie starzenia się, [w:] Człowiek w wieku podeszłym we wspótczesnym społeczeństwie, Wydawnictwo UMP, Poznań 2009.

Kluczyńska U., Stary mężczyzna we współczesnym społeczeństwie. Konteksty społeczne i kulturowe, [w:] Człowiek w wieku podeszłym we wspótczesnym społeczeństwie, Wydawnictwo UMP, Poznań 2009.

Kostka T., Koziarska-Rościszewska M., Choroby wieku podeszłego, Wydawnictwo Lekarskie PZWL, Warszawa 2009.

Kropińska S., Zasadzka E., Wieczorowska-Tobis K., Dyskryminacja osób w wieku podeszłym w placówkach służby zdrowia, [w:] Człowiek w wieku podeszłym we wspótczesnym społeczeństwie, Wydawnictwo UMP, Poznań 2009.

Phillipson C., Graham A., Aging and the Life Course, [w:] The Blackwell Companion to the Sociology of Families, Blackwell Publishing, Oxford 2007.

Pinquart M., Age differences in perceived positive affect, negative affect and affect balance in middle and old age, "Journal of Happiness Studies" 2001, no. 2.

Sęk H., Wprowadzenie do psychologii klinicznej, Wydawnictwo Naukowe Scholar, Warszawa 2001.

Sygit E., Ossowski R., Przemoc wobec osób starszych ze względu na wiek, płeć i wyksztatcenie, „Gerontologia Polska” 2008, nr 16.

Szewczyk K., Bioetyka. Pacjent w systemie opieki zdrowotnej, Wydawnictwo Naukowe PWN, Warszawa 2009.

Thomson E. H. Jr., Older Man as Invisible Man in Contemporary Society, [w:] tenże, Men's Lives, Boston-London-Toronto-Sidney-Tokyo-Singapore 1998.

Wenger G. C., Morale in old age: a review of the evidence, „International Journal of Geriatric Psychiatry" 1992, no. 7.

Wydział Nauk o Zdrowiu Uniwersytetu Medycznego im. Karola Marcinkowskiego $w$ Poznaniu w latach 1975-2015. Czterdzieści lat w służbie uniwersyteckich nauk medycznych, red. M. Musielak, W. Samborski, Wydawnictwo UMP, Poznań 2015. 


\section{Netografia}

Ageism Hurts [dostęp: 02.04.2016], http://ageismhurts.org/what-is-ageism.

Brower A., Is It Time To Take a Harder Look at the QALY?, „National Center for Biotechnology Information", http://www.ncbi.nlm.nih.gov/pmc/articles/PMC 2706179/ [dostęp: 02.04.2016].

Demografia Polski - Raport GUS, http://www.clf.net.pl/15-demografia-polski, [dostęp: 02.04.2016].

Derejczyk J., Bień B., Kokoszka-Paszkot J., Szczygieł J., Gerontologia i geriatria w Polsce na tle Europy - czy należy inwestować w ich rozwój w naszym kraju?, „Gerontologia Polska" 2008, nr 3 (16), https://journals.viamedica.pl/gerontologia_polska/article/view/18941 [dostęp: 30.03.2016].

Eurostat: Proportion of population aged 65 and over, 2 marca 2015, http://epp.eurostat.ec.europa.eu/tgm/table.do?tab=table\&init $=1 \&$ plugin $=1 \&$ language $=e n \& p c o$ de $=$ tps00028 [dostęp: 02.04.2016].

Galewicz W., Kryterium wieku $w$ racjonowaniu zasobów zdrowotnych, „Forum PTB i INCET", http://www.incet.uj.edu.pl/dzialy.php?l=pl\&p=30\&i$=388 \& \mathrm{~m}=19 \& \mathrm{n}=1 \& \mathrm{z}=0 \& \mathrm{k}=43$ [dostęp: 02.04.2016].

Godlewska I., Anna jest chora na raka jajnika, ale lek jej nie przystuguje, „Wyborcza. pl", 25 lutego 2015, http://wyborcza.pl/1,75248,17479257,Anna_jest_chora_na_ raka_jajnika_ale_lek_jej_nie_przysluguje.html [dostęp: 02.04.2016].

„NICE - National Institute for Health and Care Excellence”, https://www.nice.org. uk/news, [dostęp: 02.04.2016].

Rozwadowska A., Prof. Tobis-Wieczorkowska: W Poznaniu jest tylko kilku geriatrów. Ale coś się powoli zmienia, „Głos Wielkopolski”, 1 marca 2013, http://www. gloswielkopolski.pl/artykul/772273,prof-tobiswieczorkowska-w-poznaniujest-tylko-kilku-geriatrow-ale-cos-sie-powoli-zmienia,1,id,t,sa.html [dostęp: 02.04.2016].

\section{Abstract \\ The Distribution of Health Resources Due to the Age of the Patient. The Voice in Defence of the Quality of Life of the Old}

According to the new Eurostat's and Gus's research, in Poland and in the other European countries the population's aging process is proceeding. In the researchers' opinion, the growth of the number of the old causes the constant rise in the demand 
of health services. Because of that, from among different goods, the health is the most precious to humans.

As Kazimierz Szewczyk has correctly established, the health value is high, because it belongs to limited resources. Not all of the medical services are guaranteed by healthcare system, therefore the need of implementing economical rules in the process of allocation of limited health values important.

In the opinion of numerous doctors, psychologists and ethics, e.g. Jarosław Derejczyk, Barbara Bień, Janina Kokoszka-Paszkot and Joanna Szczygieł patients who are old belong to disadvantaged group. The patients are not given the priority in access to health benefits, and they are also discrimanated.

In this article I am going to enumerate and describe the medical methods, that are used in economical distribution of health care benefits. Later I'll explain, why during distribution of benefits, the quality of life of old people, and not only their register age, should be taken into consideration

Keys words: the old, ageism, geriatrics, health care benefits, limited goods in medicine 